\title{
Variability analysis and inter-genotype comparison of human respiratory syncytial virus small hydrophobic gene
}

\author{
Jelena Ivancic-Jelecki ${ }^{1,2^{*}}$ D. Anamarija Slovic ${ }^{1,2}$, Sunčanica Ljubin-Sternak ${ }^{3,4}$, Gordana Mlinarić Galinović 4,5
} and Dubravko Forcic ${ }^{1,2}$

\begin{abstract}
Background: Small hydrophobic (SH) gene is one of the mostly diverse genomic regions of human respiratory syncytial virus (HRSV). Its coding region constitutes less than $50 \%$ of the complete gene length, enabling $\mathrm{SH}$ gene to be highly variable and the SH protein highly conserved. In standard HRSV molecular epidemiology studies, solely sequences of the second hypervariable region of the glycoprotein gene (HVR2) are analyzed. To what extent do the strains identical in HVR2 differ elsewhere in genomes is rarely investigated. Our goal was to investigate whether diversity and inter-genotype differences observed for HVR2 are also present in the SH gene.
\end{abstract}

Methods: We sequenced 198 clinical samples collected within a limited area and time frame. In this HRSV collection, rapid and significant changes in HVR2 occurred.

Results: Over 20\% of strains from this pool (containing HRSV genotypes NA1, ON1, GA5, BA9 and BA10) would be incorrectly assumed to be identical to another strain if only the HVR2 region was analysed. The majority of differences found in SH gene were located in the 5' untranslated region (UTR). Seven indels were detected, one was genotype GA5 specific. An in-frame deletion of 9 nucleotides (coding for amino acids 49-51) was observed in one of group A strains. Fifteen different SH protein sequences were detected; $68 \%$ of strains possessed the consensus sequence and most of others differed from the consensus in only one amino acid (only 4 strains differed in 2 amino acids). The majority of differing amino acids in group A viruses had the same identity as the corresponding amino acids in group B strains. When analysis was restricted to strains with identical HVR2 nucleotide sequences and differing SH protein sequences, $75 \%$ of differences observed in the SH ectodomain were located within region coding for amino acids 49-51.

Conclusions: Basing HRSV molecular epidemiology studies solely on HVR2 largely underestimates the complexity of circulating virus populations. In strain identification, broadening of the genomic target sequence to $\mathrm{SH}$ gene would provide a more comprehensive insight into viral pool versatility and its evolutionary processes.

Keywords: Human respiratory syncytial virus, HVR2, Molecular epidemiology, Molecular evolution, SH, Small hydrophobic gene, Virus variability

\footnotetext{
* Correspondence: jivancic@unizg.hr

${ }^{1}$ Centre for Research and Knowledge Transfer in Biotechnology, University of

Zagreb, Rockefellerova 10, 10000 Zagreb, Croatia

${ }^{2}$ Scientific Center of Excellence for Viral Immunology and Vaccines, CerVirVac,

Zagreb, Croatia

Full list of author information is available at the end of the article
}

(c) The Author(s). 2018 Open Access This article is distributed under the terms of the Creative Commons Attribution 4.0 International License (http://creativecommons.org/licenses/by/4.0/), which permits unrestricted use, distribution, and reproduction in any medium, provided you give appropriate credit to the original author(s) and the source, provide a link to the Creative Commons license, and indicate if changes were made. The Creative Commons Public Domain Dedication waiver (http://creativecommons.org/publicdomain/zero/1.0/) applies to the data made available in this article, unless otherwise stated. 


\section{Background}

Human respiratory syncytial virus (HRSV) belongs to the Orthopneumovirus genus of the Pnemoviridae family [1] and has non-segmented RNA of negative polarity as its genome. The genome is approx. 15,200 nucleotides (nts) long, comprising 10 genes that encode for 11 proteins. The HRSV strains are divided into groups A and B based on genetic and antigenic differences [2].

There are three proteins on the surface of mature HRSV virions: glycoprotein (G), fusion protein (F) and small hydrophobic $(\mathrm{SH})$ protein. $\mathrm{SH}$ protein is present at very low amounts $[3,4]$. G and $F$ are important for attachment and fusion with the target cell, respectively $[5,6]$ and they can elicit the production of neutralizing antibodies $[7,8]$.

$\mathrm{SH}$ protein is a short transmembrane protein (typically 64 amino acids for group A and 65 for group B) that is anchored by a hydrophobic signal-anchor sequence near the $\mathrm{N}$-terminus, with the $\mathrm{C}$ - terminus oriented extracellularly. The $\mathrm{SH}$ ectodomain is only weakly immunogenic $[4,9]$. In infected cells, SH protein accumulates mostly in lipid rafts of the Golgi and of the endoplasmic reticulum [3]. It is a viroporin, forming a transmembrane pentameric ring that functions as a channel for cations and small molecules $[10,11]$. HRSV SH protein blocks or delays apoptosis through inhibition of the TNF- $\alpha$ signalling pathway [12] but the mechanism is still not fully elucidated.

In molecular epidemiology studies, HRSV surveillance and genotyping are based on sequences of the second, C-terminal hypervariable region of the G gene (HVR2). In frame duplications of 72 and 60 nts have occurred within this region, leading to emergence of group A strains belonging to genotype ON1 (which originated from NA1, and was firstly detected in 2010 [13]) and of group B strains belonging to BA genotypes, respectively.

To what extent do the strains identical in HVR2 differ elsewhere in their genomes is rarely investigated. In the analysis by Agoti et al. such strains differed by at least 1 and up to 9 nts across the complete genome [14].

Next to HVR2, the most diverse HRSV genomic region is the $\mathrm{SH}$ gene [15]. Unlike all other HRSV genes, the $\mathrm{SH}$ coding region constitutes less than 50\% of the complete gene length (the coding regions of other HRSV genes constitute ca. 75-99\% of the gene length). Following our previous analysis of HVR2 sequences of strains detected within a limited geographical area (the Zagreb region) and limited time frame (March 2011 to March 2014) [16], the goal of this study was to investigate whether virus variability and inter-genotype differences observed for HVR2 are also present in the $\mathrm{SH}$ gene. Within this pool of viruses, rapid and significant genetic changes have occurred in HVR2 [16]. The subset of strains analysed in this research belong to 3 HRSV A
(NA1, ON1 and GA5) and 2 HRSV B genotypes (BA9 and BA10) and it included all the genotypes that were detected in Zagreb, 03/2011-03/2014. These are also the most common HRSV genotypes detected worldwide in the last decade.

\section{Methods \\ Clinical samples}

Nasopharyngeal secretions were obtained from children who were in-patients with acute respiratory infections, hospitalized mostly due to bronchiolitis or pneumonia [16]. Based on the availability of the material, 220 samples with previously determined sequences of the HVR2 region and genotype [16] were chosen for $\mathrm{SH}$ gene analysis. Sequences were obtained from 198 samples.

\section{Reverse transcription, PCR and sequencing}

Total RNA was extracted from $500 \mu \mathrm{L}$ of clinical samples according to the method reported by Chomczynski and Mackey [17]. Reverse transcription was performed at $42{ }^{\circ} \mathrm{C}$ for $60 \mathrm{~min}$, in a reaction mix containing $10 \mu \mathrm{L}$ of isolated RNA, 1× PCR buffer (GE Healthcare, UK), $0.1 \mathrm{mM}$ of each dNTP, $20 \mathrm{U}$ of RNase inhibitor (Thermo Fisher Scientific, USA), $1.25 \mathrm{mM} \mathrm{MgCl}_{2}, 2.5 \mathrm{mM}$ of random hexanucleotide primers and $50 \mathrm{U}$ of $\mathrm{MuLV}$ reverse transcriptase (Thermo Fisher Scientific, USA) in a final volume of $20 \mu \mathrm{L}$.

Nested PCR was carried out with two sets of primers. For the first amplification, forward $\mathrm{SH} 1$ (5' CACA GTKACTGACAAYAAAGGAGC 3') and reverse F164 (5' GTTATGACACTGGTATACCAACC 3') primers were used, followed by the second amplification with the SH3 (5' CAGATCATCCCAAGTCATT 3') and SH4 (5' TGATTGAGAGTGTCCCAGGT 3') primer pair for HRSV A strains and the SH5 (5' AGCCATTGTCTGCC AGAYCTAGAG 3') and SH4 primer pair for HRSV B strains.

Ten microliters of the reverse transcription reaction mix was used for the first amplification, whereas $2 \mu \mathrm{L}$ of the first amplification mixture was used for the second PCR. PCR reaction mixtures contained $1 \times$ PCR buffer (GE Healthcare, UK), $10 \mu \mathrm{M}$ of each dNTP, $0.25 \mathrm{mM}$ $\mathrm{MgCl}_{2}, 0.25 \mu \mathrm{M}$ of each primer and $5 \mathrm{U}$ of Taq polymerase (GE Healthcare, UK). PCR conditions for the first amplification were: $95{ }^{\circ} \mathrm{C}$ for $5 \mathrm{~min}, 40$ cycles of $95{ }^{\circ} \mathrm{C} /$ $30 \mathrm{~s}, 50{ }^{\circ} \mathrm{C} / 30 \mathrm{~s}, 68^{\circ} \mathrm{C} / 2 \mathrm{~min}$, followed by final extension at $68{ }^{\circ} \mathrm{C}$ for $7 \mathrm{~min}$. The second PCR was performed under the same conditions, except the primer annealing temperature was $52{ }^{\circ} \mathrm{C}$, and the extension step was shortened to $1 \mathrm{~min}$.

The amplification products of ca. 600 nts were separated on a $1.5 \%$ agarose gel. Sequencing reactions were set up with gel purified DNA, one of the specific primers used in the second PCR and a BigDye Terminator 
v3.1 Cycle Sequencing Kit (Thermo Fisher Scientific, USA) according to the manufacturer's protocol. Sequencing and sequence analysis were performed on a 3130 Genetic Analyzer (Thermo Fisher Scientific, USA). Obtained sequences were submitted to National Center for Biotechnology Information (NCBI) database, under acc. Nos. MF479446 - MF479565 (HRSV A) and MF479566 MF479643 (HRSV B).

The HRSV genomic region used in the analyses (referred to as SHseg) spanned bases 4172-4642 of strain A2 (acc. no. M11486) and 4218-4689 of B1 (acc. no. AF013254), which are the prototype strains of group A and $B$, respectively.

\section{Collection of HVR2 sequences}

HVR2 sequences included in this study are a subset of sequences determined during our previous study on HRSV molecular epidemiology [16]. HVR2 region spanned bases 5274-5543 of strain A2 and 652-981 of BA4128/99B. The length of HVR2 is 270 or 242 nts for group A and 270 or 330 nts for group B.

\section{Sequences retrieved from $\mathrm{NCBI}$ database}

All available HRSV sequences that possessed AAAA AAGTCA at the end of $\mathrm{SH} 3^{\prime}$ untranslated region (UTR) and beginning of $\mathrm{SH}-\mathrm{G}$ intergenic region were downloaded from NCBI database. Besides the 3 strains sequenced in this study, 14 sequences were found, acc. Nos. KF826826, KJ672447, KJ672462, KJ672474, KJ672479, KJ672483, KU950473, KU950479, KU950487, KU950501, KU950564, KU950609, KU950616 and KX765891.

\section{Multiple sequence alignments and analyses}

Sequences were aligned using BioEdit, version 7.2.5 and ClustalX 2.1. Sequence conservation (defined as the percentage of genomic positions identical in all strains; gaps were ignored during computing) and mean $p$-distance (proportion of nucleotide sites at which two sequences being compared are different) were calculated using MEGA software v6.06.

The ratio of the number of non-synonymous substitutions per non-synonymous site and synonymous substitutions per synonymous site $(\mathrm{dN} / \mathrm{dS})$ was calculated with the single-likelihood ancestor counting method (SLAC) available on the Datamonkey server (http:// www.datamonkey.org/).

\section{Phylogenetic analysis}

Phylogenetic trees were generated using the maximum likelihood method with MEGA software v6.06, under the most appropriate model of nucleotide substitution determined with jModeltest v2.1.4. Bootstrap probabilities for 1000 iterations were calculated to evaluate confidence estimates. Values higher than $70 \%$ were considered significant.

\section{Selective pressure and glycosylation analysis}

Codon-based analysis of selective pressure for $\mathrm{SH}$ gene sequences was performed using the HyPhy package available on the Datamonkey server. Four different methods were used: SLAC, fixed-effects likelihood, internal branch fixed-effects likelihood and mixed effects model of evolution. Sites were considered positively or negatively selected if (a) they met the cut-off criteria of $p$-value of $<0.1$; or (b) they were recognized by at least two methods.

NetOGlyc 4.0 server (http://www.cbs.dtu.dk/services/ NetOGlyc/) and NetNGlyc 1.0 servers (http://www.cbs. $\mathrm{dtu} . \mathrm{dk} /$ services/NetNGlyc/) were used for $\mathrm{O}$ - and $\mathrm{N}$-glycosylation site prediction, respectively.

\section{Results}

\section{Sequence variability and phylogeny}

The SHseg spanned the entire SH gene (coding, 5' UTR and 3' UTR), SH-G intergenic region and G gene 5' UTR (Fig. 1). We obtained sequences of 120 HRSV A strains; 83, 34 and 3 were NA1, ON1 and GA5 strains, respectively. Seventy-eight sequences belonged to HRSV B group; 77 belonged to genotype BA9 and 1 to BA10. The nucleotide length of the consensus sequence was 469 nts for group A and 472 nts for group B strains. Seven indels were detected (Fig. 1). In group A deletions were at positions 4190, 4318-4316, in poly A tail (4577-4581) and at positions 4582-4583 in reference to the consensus sequence A2; insertions were an additional adenosine in poly A tail and a guanosine after nucleotide 4581 (Fig. 1). In group $B$, a deletion of an adenosine in poly $A$ tail was observed (position 4626-4630 in reference to the consensus sequence B1). Five indels were found only within a single genotype, but in very low percentages. Deletion of 2 nts at the beginning of the $\mathrm{SH}-\mathrm{G}$ intergenic region in GA5 strains, preceded by 6 adenosines ${ }^{1}$ was found in $100 \%$ of our GA5 strains and only in GA5 genotype (and therefore could be classified as genotype specific). Our viral pool contained only 3 GA5 strains, identical in both HVR2 and SHseg and all collected in February 2014. Therefore we searched for other HRSV sequences that possess AAAA AAGTCA at the end of SH 3' UTR and beginning of $\mathrm{SH}-\mathrm{G}$ intergenic region in NCBI database. Fourteen sequences were retrieved and all belong to genotype GA5 (Additional file 1: Figure S1).

We analysed if viruses with identical HVR2 sequences (considered to be identical viruses in standard molecular evolutionary analyses) had differences in SHseg. Some strains identical at HVR2 differed at SHseg, and vice versa, strains different at HVR2 were identical at SHseg (Table 1, Additional file 2: Table S1). In our HRSV pool, 


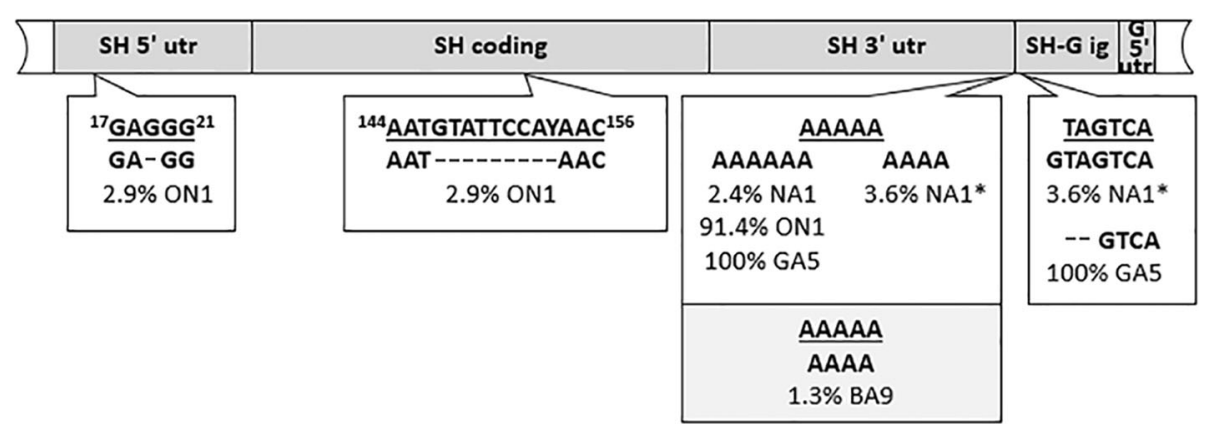

Fig. 1 Variations in length detected in SHseg. Variations in group A strains are shown in white rectangles; in group B strains in gray. Underlined sequences are consensus sequences. The percentage of strains possessing presented non-consensus sequences is shown. Asterisks indicate that both variations were in the same NA1 strain

if strains were inferred as being the same based only on HVR2 sequence analysis, 44 strains (22.3\%) would have been falsely characterized.

As expected, none of SHseg sequences found among HRSV A strains was detected within HRSV B pool, but there was also no overlapping between the genotypes. $I$. $e$., none of the SHseg sequences present in any of the 5 HRSV genotypes included in the study were detected in strains belonging to another genotype.

The phylogenetic analysis based on SHseg (Fig. 2) did not discriminate NA1 and ON1 genotypes. NA1 and ON1 strains were placed within a common clade, separated from GA5 strains and from group B lineage. In group B, a single BA10 strain is positioned among the BA9 strains (Fig. 2).

\section{Nucleotide variability}

We calculated the percentage of conservation and mean p-distance within complete HVR2, complete SHseg and within each individual region of the SHseg (Table 2).
Compared to HVR2, SHseg showed higher sequence conservation in all genotypes. Difference in variability was especially evident when solely the coding region of the $\mathrm{SH}$ gene was compared to HVR2 (HVR2 consists of 96.5\% of coding region (for ON1), $95.6 \%$ or $96.7 \%$ (for NA1) and $90.9 \%$ or $97.3 \%$ (for BA9)). The evolutionarily newest genotype ON1 showed the highest conservation percentage and the lowest $p$-distance values (not taking into account 3 GA5 strains). When individual genomic regions within $\mathrm{SHseg}$ were compared, differences among genotypes were observed: all HRSV A strains were identical at the 5' UTR of the G gene, but ON1 strains showed a smaller percentage of conserved sites in the 5 UTR of the $\mathrm{SH}$ gene, compared to other regions. In NA1 strains, the conservation percentage was similar throughout the SHseg (differing by no more than $4.6 \%$, excluding the 5' UTR of the G gene). Among BA9 strains, a smaller percentage of conserved sites was again observed in the 5' UTR of the SH gene, while the values for other regions were comparable.

Table 1 Comparison of HRSV sequence clustering based on HVR2 vs clustering based on SHseg

\begin{tabular}{|c|c|c|c|c|c|}
\hline HRSV group & $A$ & & & B & \\
\hline genotype & NA1 & ON1 & GA5 & BA9 & BA10 \\
\hline total no. of strains & 83 & 34 & 3 & 77 & 1 \\
\hline of different HVR2 sequences & 37 & 22 & 1 & 31 & n.a. ${ }^{a}$ \\
\hline no. of different SHseg sequences & 30 & 20 & 1 & 21 & n.a. \\
\hline $\begin{array}{l}\text { no. of strains identical at HVR2 that } \\
\text { are also identical at SHseg (divided } \\
\text { in groups of identical sequences) }\end{array}$ & $\begin{array}{l}45 \\
(3+2+6+2+3+2+13 \\
+3+2+3+2+2+2)\end{array}$ & $\begin{array}{l}14 \\
(2+2+2+3+3+2)\end{array}$ & $\begin{array}{l}3 \\
(3)\end{array}$ & $\begin{array}{l}44 \\
(5+8+8+2+2+15+2+2)\end{array}$ & n.a. \\
\hline $\begin{array}{l}\text { no. of strains possessing unique } \\
\text { sequences at HVR2 and at SHseg }\end{array}$ & 11 & 11 & 0 & 7 & n.a. \\
\hline $\begin{array}{l}\text { no. of strains identical at HVR2 and } \\
\text { different at SHseg (divided in groups } \\
\text { of identical HVR2 sequences) }\end{array}$ & $\begin{array}{l}19 \\
(4+2+2+4+5+2)\end{array}$ & $\begin{array}{l}8 \\
(2+2+2+2)\end{array}$ & 0 & $\begin{array}{l}17 \\
(2+2+2+2+4+3+2)\end{array}$ & n.a. \\
\hline $\begin{array}{l}\text { no. of strains identical at SHseg and } \\
\text { different at HVR2 (divided in groups } \\
\text { of identical SHseg sequences) }\end{array}$ & $\begin{array}{l}26 \\
(7+9+4+2+2+2)\end{array}$ & $\begin{array}{l}7 \\
(7)\end{array}$ & 0 & 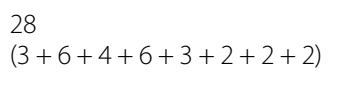 & n.a. \\
\hline
\end{tabular}

${ }^{a}$ n.a. not applicable 


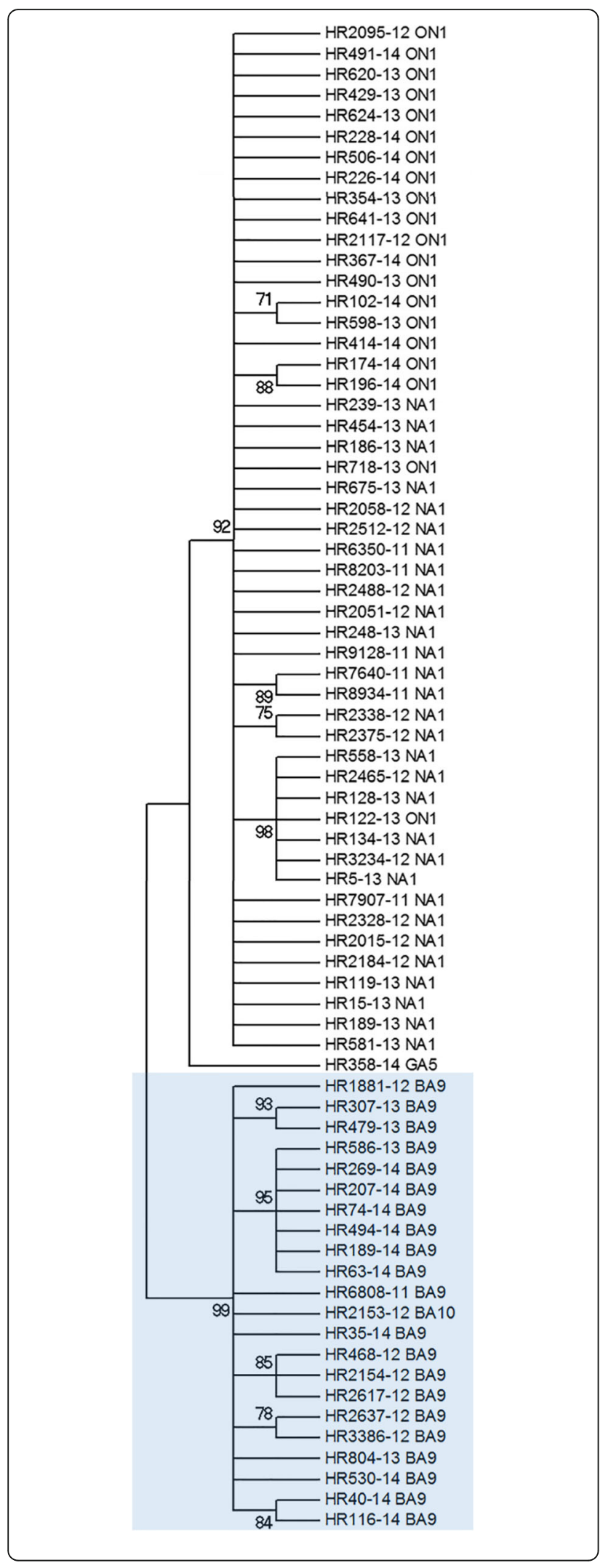

Fig. 2 Phylogenetic analysis based on SHseg. The tree was generated using the Maximum Likelihood method, General Time Reversible model. The numbers are bootstrap values determined for 1000 iterations; the tree was condensed using a cut-off value of $70 \%$. Strain genotypes (determined by phylogenetic analysis based on HVR2) are shown next to strain names. Blue background indicates group B strains

Unlike group A, the 5' UTR of the group B G gene was not completely conserved, but the only difference among 78 strains was in the last nucleotide of this region; $60 \%$ of strains had a cytosine and $40 \%$ an adenine.

\section{Variability of protein sequences}

The strains analysed in this study possessed 10 and 5 different $\mathrm{SH}$ protein sequences in the HRSV A and HRSV B strains, respectively (Fig. 3). The SH protein sequences identical to the group A or B consensuses was obtained in $67.7 \%$ of strains. The others differed from the consensuses in only one amino acid (Fig. 3), with two exceptions: a) the 3 GA5 strains differed in 2 amino acids; b) in a single strain, RSV5-13 belonging to genotype NA1, amino acids $49-51$ are missing. A single $\mathrm{N}$-glycosylation site was predicted for all strains (the same one, Fig. 3); no potential O-glycosylation sites were recognised.

In the intracellular and transmembrane protein region (amino acids 1-41), variability was seen only in group A strains and 4 out of 5 observed differences were such that differing amino acids had the same identity as corresponding amino acid in group B strains (shaded areas in Fig. 3). Sequence coding for the fifth amino acid difference, S35F, observed in only one ON1 strain (HR22614 from 2014), presents so far a unique $\mathrm{SH}$ gene sequence, when compared to all sequences available in open public databases.

Greater versatility, including the deletion of 3 amino acids, was observed in the SH ectodomain. Again, two amino acid differences observed within HRSV A strains were such that differing amino acids had the same identity as the corresponding amino acids in group B strains (shaded areas in Fig. 3). Among the HRSV B strains, differences in the amino acid sequence were seen only within the SH ectodomain. Out of 9 amino acid differences observes in the $\mathrm{SH}$ ectodomain (in both groups, Fig. 3), 5 were in protein region 49-51.

The codon-based analysis of selective pressure did not identify any positively selected codon and the mean $\mathrm{dN} /$ $\mathrm{dS}$ values were low: $0.13,0.29$ and 0.15 for the NA1, ON1 and BA9 genotypes, respectively, indicating that substitutions are not favoured and are purified from the population.

The last analysis was restricted to strains identical in HVR2 nucleotide sequences and differing in SH protein 
Table 2 Conservation percentage and mean p-distance for HVR2, complete SHseg and individual genomic regions within SHseg

\begin{tabular}{|c|c|c|c|c|c|c|c|c|}
\hline \multirow[t]{2}{*}{ group } & \multirow{2}{*}{$\begin{array}{l}\text { genotype } \\
\text { (no. of } \\
\text { samples) }\end{array}$} & \multirow[t]{2}{*}{ HVR2 } & \multirow[t]{2}{*}{ SHseg } & \multicolumn{5}{|c|}{$\begin{array}{l}\text { individual SHseg genomic regions } \\
\text { (max. Length in nt for HRSV A and HRSV B, respectively) }\end{array}$} \\
\hline & & & & $\begin{array}{l}\text { SH gene } \\
5^{\prime} \text { UTR } \\
(84,85)\end{array}$ & $\begin{array}{l}\text { SH } \\
\text { coding } \\
(195,198)\end{array}$ & $\begin{array}{l}\text { SH gene } \\
3^{\prime} \text { UTR } \\
(132,130)\end{array}$ & $\begin{array}{l}\text { intergenic } \\
\text { region } \\
(45,44)\end{array}$ & $\begin{array}{l}\text { G gene } \\
5^{\prime} \text { UTR } \\
(15,15)\end{array}$ \\
\hline \multirow[t]{9}{*}{ A } & ON1 (34) & & & & & & & \\
\hline & a & 88.0 & 91.5 & 81.0 & 94.4 & 90.2 & 90.9 & 100 \\
\hline & $b$ & 0.017 & 0.007 & 0.019 & 0.004 & 0.009 & 0.007 & 0 \\
\hline & NA1 (83) & & & & & & & \\
\hline & a & 78.5 & 89.8 & 88.1 & 91.3 & 88.6 & 86.7 & 100 \\
\hline & $b$ & 0.028 & 0.015 & 0.025 & 0.011 & 0.018 & 0.007 & 0 \\
\hline & overall $^{\mathrm{b}}$ (12 & & & & & & & \\
\hline & a & 67.3 & 79.4 & 71.4 & 85.1 & 76.5 & 71.1 & 100 \\
\hline & $b$ & 0.038 & 0.018 & 0.029 & 0.012 & 0.023 & 0.013 & 0 \\
\hline \multirow[t]{6}{*}{ B } & BA9 (77) & & & & & & & \\
\hline & a & 81.5 & 89.6 & 78.8 & 93.9 & 89.2 & 90.9 & 93.3 \\
\hline & $b$ & 0.023 & 0.020 & 0.040 & 0.011 & 0.021 & 0.015 & 0.032 \\
\hline & overall $^{\complement}$ (78 & & & & & & & \\
\hline & a & 78.8 & 87.5 & 76.5 & 92.9 & 88.5 & 79.5 & 93.3 \\
\hline & $b$ & 0.023 & 0.020 & 0.040 & 0.011 & 0.021 & 0.017 & 0.032 \\
\hline
\end{tabular}

aTR, untranslated region

broup A includes strains belonging to ON1, NA1 and GA5 (3 strains identical in HVR2 and in SHseg)

cgroup B includes BA9 strains and a single BA10 strain

sequences. Eight groups of such strains were identified (Table 3), in 4 of them the differences were in the SH ectodomain. From those 4, in 3 groups (2 HRSV A and 1 HRSV B), the differences were located within the SH protein region $49-51$, including the case where these 3 amino acids were missing.

\section{Discussion}

Due to the fact that SH gene UTRs are relatively long (when compared to the coding region of the gene) and that the majority of mutations occur in them, HRSV SH gene is characterized by high variability while the $\mathrm{SH}$ protein remains highly conserved.

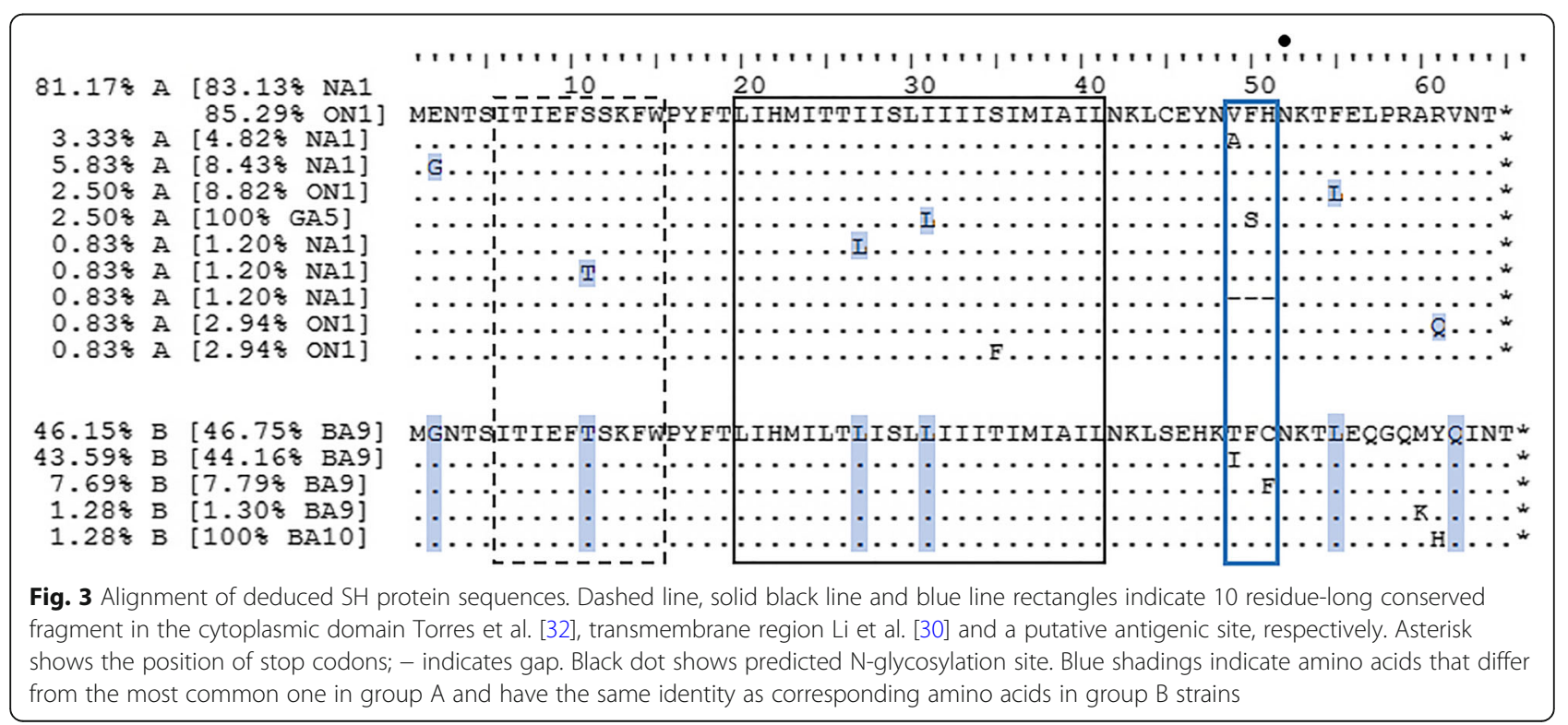


Table 3 Differences between SH proteins among strains identical at the HVR2 region

\begin{tabular}{|c|c|c|c|c|c|}
\hline $\begin{array}{l}\text { Strains identical in HVR2 nucleotide } \\
\text { sequences and differing in SH } \\
\text { protein sequences }\end{array}$ & Group & Genotype & $\begin{array}{l}\text { Amino acid } \\
\text { position }\end{array}$ & $\begin{array}{l}\text { Amino acid } \\
\text { identity }\end{array}$ & SH protein region \\
\hline HR15-13 & A & NA1 & 2 & G & cytoplasmic \\
\hline HR186-13 & & & & $E$ & \\
\hline HR119-13 & A & NA1 & 2 & E & cytoplasmic \\
\hline HR129-13 & & & & G & \\
\hline HR175-13 & A & NA1 & 2 & G & cytoplasmic \\
\hline HR372-13 & & & & E & \\
\hline HR116-13 & A & NA1 & 11 & S & cytoplasmic \\
\hline HR134-13 & & & & T & \\
\hline HR2033-12 & A & NA1 & 49 & V & ectodomain \\
\hline HR110-15 & & & & A & \\
\hline RSV3234-12 & A & NA1 & $49-51$ & VFH & ectodomain \\
\hline RSV5-13 & & & & - & \\
\hline HR40-14 & B & BA9 & 49,51 & $\mathrm{~T}, \mathrm{~F}$ & ectodomain \\
\hline HR189-14 & & & & I, C & \\
\hline HR2154-12 & B & BA9 & 60 & K & ectodomain \\
\hline HR2253-12 & & & & M & \\
\hline
\end{tabular}

Legend:- gap

Besides the complete $\mathrm{SH}$ transcript, the genomic segment we analysed also included its two downstream regions, stopping immediately before the start codon of the $G$ protein mRNA. The last two regions were included because they are known to play a role in the transcriptional regulation of both upstream and downstream genes [18-20].

We analysed whether a difference in the diversity of the $\mathrm{SH} / \mathrm{G}$ junction (i.e. of the sequences between the stop codon of the upstream gene and the start codon of the downstream gene) among HRSV genotypes could be observed. A sequence characteristic only for GA5 strains was observed, but not all previously reported GA5 strains possess this sequence [20]. Whether it represents an evolutionary novelty, specific for recent GA5 strains requires further investigation (the oldest GA5 strain in our analysis was from Mexico, from 2004).

The overall nucleotide diversity of SHseg was investigated using two methods: conservation percentage that is not influenced by the number of identical sequences; and $p$-distance that is, and therefore, defines more precisely diversity within this particular HRSV population. The results of both methods were concordant. The level of genetic diversity observed in SHseg was not comparable to the one detected in HVR2, except in the 5' UTR of the genotypes with prolonged $\mathrm{G}$ gene (ON1 and BA9) which gained striking dominance within the short timespan we analysed. On the contrary, the other SH UTR and $\mathrm{SH}-\mathrm{G}$ intergenic region showed less variability in
ON1 and BA9 strains, when compared to NA1 genotype.

The current HRSV genotyping and molecular surveillance system is based on HVR2 [21, 22], a quite short genomic segment. It partitions HRSV strains in over 15 group A and over 20 group B genotypes. Regarding phylogeny, SHseg in not as informative as HVR2. E.g. in analyses based on HVR2, ON1 and NA1 strains are placed on different branches, even when one copy of the duplicated segment is excluded from the analysis [23]. Still, basing molecular epidemiology studies only on HVR2 may be quite misleading. In our pool of HRSV strains, over $20 \%$ of them would be incorrectly assumed to be identical to another strain if only the HVR2 region was analysed. An alternative HRSV genotyping scheme has recently been proposed [24], based on the complete $\mathrm{G}$ protein ectodomainwhich is twice longer than HVR2. Although this would increase the discrimination between strains, it is still focused solely on one protein gene. The G gene is non-representative of the HRSV genome, as it is marked by elevated substitution rates (attributed to relaxed selective constraints [25]) and a flip-flop substitution pattern [26]. Broadening the target genome sequence to $\mathrm{SH}$ (whose length in our analysis was 401-411 nts in group A, 412 or 413 in group B) or only to SH 5' UTR (in our analysis, this was a region of 83 or 84 nts in group A, 85 in group B) would provide better insight into the interrelation between molecular epidemiology and molecular and evolutionary dynamics. 
After the translation of our genomic sequences, only 15 different protein sequences were obtained. Although group A and group B strains diverged approximately 350 years ago [27], the majority of amino acids which differ from the consensus in group A have the same identity as corresponding amino acids in group B strains. This indicates that the variability of the $\mathrm{SH}$ protein is not only low, but is also restricted. Based on the fact that HVR2 has the highest evolutionary rates, we concentrated on strains possessing the same HVR2 nucleotide sequences, but still differing in their $\mathrm{SH}$ protein sequences. Those are the strains most likely to be highly similar and therefore we hypothesized that the observed differences could be a result of selective pressure. Out of 4 sets of strains with differences in the $\mathrm{SH}$ ectodomain, in 3 sets the differences were in $\mathrm{SH}$ protein region 4951. In fact, besides S35F the only amino acid differences observed in group A strains which differed from the group B consensus, were located within 49-51 region. In our viral pool, which was very limited both geographically and temporally, $6.7 \%$ of group A strains and $51.3 \%$ of group B strains possessed mutation in region 49-51.

Our hypothesis that $\mathrm{SH}$ region $49-51$ is an antigenic site still needs confirmation, but the same amino acids were shown to be highly variable by Lima et al. [28]. Their analysis was performed on strains belonging to HRSV genotypes different from ours and detected in Brazil in 2004-2005. Besides finding T49I variability (as observed by us), $\mathrm{P}$ and $\mathrm{A}$ at position 49 were also reported among group B strains. Chen et al. [29] detected variability in the same region in American HRSV strains from 1998 to 1999 [29]. In group A, the most common amino acid at position 49 was $\mathrm{V}$ (the same as in our analysis), but I was also observed. Among group B strains, at position 51, besides the most common amino acid $\mathrm{C}$ and $\mathrm{F}$ (the same as in our analysis), Chen et al. also identified $Y$ [29].

A deletion of 9 nts coding for amino acids 49-51 was found in the $\mathrm{SH}$ gene sequence of an NA1 strain from January 2013. The deletion was found only in this strain that caused a bronchiolitis in a 2-month-old child. The deletion was confirmed by 3 independent RNA isolations and preparations of DNA for sequencing. During the same HRSV epidemic, strain RSV3234-12 (from November 2012) was detected in a sample from a 4-month-old child with bronchiolitis. The two strains are identical in the $\mathrm{SH}, \mathrm{G}$ an $\mathrm{F}$ genes, except for the fact that RSV3234-12 does not possess this deletion in the $\mathrm{SH}$ gene. Other genomic regions were not sequenced. In group A strains, H51 (which is missing from RSV5-13) is a crucial residue in the regulation of $\mathrm{SH}$ ion channel activity [30]. Together with H22, H51 plays a key role in the opening and closing mechanism of the $\mathrm{SH}$ pentameric pore, since they are located in strategic places within the chains, close to the $\mathrm{N}$ - and C-termini [30, 31]. An alternative amino acid at position 51 ( $\mathrm{Y}$, a non-basic amino acid) has been reported before, in a Brazilian GA5 strain from 2004 [28], but so far there were no reports of the deletion observed in RSV5-13. In vitro experiments regarding the functionality of the $\mathrm{SH}$ protein from RSV5-13 or modelling studies that would compare its structure to other HRSV SH proteins have not been performed.

\section{Conclusions}

Basing HRSV molecular epidemiology studies solely on HVR2 largely underestimates the complexity of circulating virus populations. In strain identification, broadening of the genomic target sequence to $\mathrm{SH}$ gene would provide a more comprehensive insight into viral pool versatility.

Unlike its gene, $\mathrm{SH}$ protein is characterized by intra-group conservation and by highly restricted inter-group variability except for amino acids 49-51, implicating that this protein region may be relevant for the antigenicity of the virus.

\section{Endnotes}

${ }^{1}$ All sequences are presented as plus strands, in the $5^{\prime}$ to $3^{\prime}$ 'orientation.

\section{Additional files}

Additional file 1: Figure S1. Phylogenetic tree of RSV strains based on HVR2 genomic segment. Tree was generated using maximum-likelihood method, based on the General Time Reversible model and discrete gamma distributed rates across sites. The scale bar indicates the proportion of nucleotide substitutions per site. Numbers are percentages of bootstrap values determined for 1000 iterations, only values above 70\% are shown. Strain designations are composed of NCBI GenBank acc. no., name and genotype. (PDF 54 kb)

Additional file 2: Table S1. Sequences identical at HVR2 or SHseg. (PDF $82 \mathrm{~kb})$

\section{Abbreviations}

$\mathrm{dN} / \mathrm{dS}$ : The ratio of number of non-synonymous substitutions per nonsynonymous site and synonymous substitutions per synonymous site; F: Fusion protein; G: Glycoprotein; HRSV: Human respiratory syncytial virus; HVR2: The second hypervariable region of the glycoprotein gene; NCBI: National Center for Biotechnology Information; nts: Nucleotides; SH: Small hydrophobic; SLAC: Single-likelihood ancestor counting method; UTR: Untranslated region

\section{Funding}

This work was supported by a grant from the Croatian Science Foundation (project number 6255 to DF), by University of Zagreb (to JI-J) and by the grant "Strengthening the capacity of CerVirVac for research in virus immunology and vaccinology", KK.01.1.1.01.0006, awarded to the Scientific Centre of Excellence for Virus Immunology and Vaccines and co-financed by the European Regional Development Fund.

\section{Availability of data and materials}

The datasets analysed during the current study are included in the published article and its additional file. 


\section{Authors' contributions}

Drafted the concept and designed the study: all authors; collected clinical samples: S.L-S. and G.M.G.; performed the experiments: J.I.-J., A.S. and D.F.; analysed the data: J.I.-J. and A.S.; wrote the paper: J.I.-J.; revised the manuscript critically for important intellectual content: all authors. All authors read and approved the final version of the manuscript.

\section{Ethics approval and consent to participate}

The study was approved by the Ethics Committees of the (a) Croatian National Institute of Public Health, (b) University Children's Hospital Zagreb, (c) University Hospital for Infectious Diseases and (d) University of Zagreb Medical School.

\section{Consent for publication}

Not applicable.

\section{Competing interests}

The authors declare that they have no competing interests.

\section{Publisher's Note}

Springer Nature remains neutral with regard to jurisdictional claims in published maps and institutional affiliations.

\section{Author details}

${ }^{1}$ Centre for Research and Knowledge Transfer in Biotechnology, University of Zagreb, Rockefellerova 10, 10000 Zagreb, Croatia. ${ }^{2}$ Scientific Center of Excellence for Viral Immunology and Vaccines, CerVirVac, Zagreb, Croatia. ${ }^{3}$ Teaching Institute of Public Health "Dr. Andrija Štampar", Mirogojska 8, 10000 Zagreb, Croatia. ${ }^{4}$ School of Medicine University of Zagreb, Šalata 3, 10000 Zagreb, Croatia. ${ }^{5}$ Croatian National Institute of Public Health, Rockefellerova 12, 10000 Zagreb, Croatia.

Received: 21 February 2018 Accepted: 10 July 2018

Published online: 18 July 2018

\section{References}

1. Afonso CL, Amarasinghe GK, Bányai K, Bào Y, Basler CF, Bavari S, et al. Taxonomy of the order Mononegavirales: update 2016. Arch Virol. 2016;161: 2351-60.

2. Mufson MA, Orvell C, Rafnar B, Norrby E. Two distinct subtypes of human respiratory syncytial virus. J Gen Virol. 1985;66:2111-24.

3. Rixon HW, Brown G, Aitken J, McDonald T, Graham S, Sugrue RJ. The small hydrophobic $(\mathrm{SH})$ protein accumulates within lipid-raft structures of the Golgi complex during respiratory syncytial virus infection. J Gen Virol. 2004; 85:1153-65.

4. Schepens B, Sedeyn K, Vande Ginste L, De Baets S, Schotsaert M, Roose K, et al. Protection and mechanism of action of a novel human respiratory syncytial virus vaccine candidate based on the extracellular domain of small hydrophobic protein. EMBO Mol Med. 2014;6:1436-54.

5. Levine S, Klaiber-Franco R, Paradiso PR. Demonstration that glycoprotein G is the attachment protein of respiratory syncytial virus. J Gen Virol. 1987;68: 2521-4.

6. Walsh EE, Hruska J. Monoclonal antibodies to respiratory syncytial virus proteins: identification of the fusion protein. J Virol. 1983;47:171-7.

7. Johnson S, Oliver C, Prince GA, Hemming VG, Pfarr DS, Wang SC, et al. Development of a humanized monoclonal antibody (MEDI-493) with potent in vitro and in vivo activity against respiratory syncytial virus. J Infect Dis. 1997;176:1215-24

8. Martinez I, Melero JA. Enhanced neutralization of human respiratory syncytial virus by mixtures of monoclonal antibodies to the attachment $(G)$ glycoprotein. J Gen Virol. 1998;79:2215-20.

9. Akerlind-Stopner B, Hu A, Mufson MA, Utter G, Norrby EJ. Antibody responses of children to the $\mathrm{C}$-terminal peptide of the $\mathrm{SH}$ protein of respiratory syncytial virus and the immunological characterization of this protein. J Med Virol. 1993;40:112-20.

10. Carter SD, Dent KC, Atkins E, Foster TL, Verow M, Gorny P, et al. Direct visualization of the small hydrophobic protein of human respiratory syncytial virus reveals the structural basis for membrane permeability. FEBS Lett. 2010;584:2786-90.
11. Gan SW, Tan E, Lin X, Yu D, Wang J, Tan GM, et al. The small hydrophobic protein of the human respiratory syncytial virus forms pentameric ion channels. J Biol Chem. 2010;287:24671-89.

12. Fuentes $S$, Tran KC, Luthra $P$, Teng MN, He B. Function of the respiratory syncytial virus small hydrophobic protein. J Virol. 2007;81:8361-6.

13. Eshaghi A, Duvvuri VR, Lai R, Nadarajah JT, Li A, Patel SN, et al. Genetic variability of human respiratory syncytial virus a strains circulating in Ontario: a novel genotype with a 72 nucleotide $\mathrm{G}$ gene duplication. PLoS One. 2012;7:e32807.

14. Agoti CN, Otieno JR, Munywoki PK, Mwihuri AG, Cane PA, Nokes DJ, et al. Local evolutionary patterns of human respiratory syncytial virus derived from whole-genome sequencing. J Virol. 2015;89:3444-54.

15. Schobel SA, Stucker KM, Moore ML, Anderson LJ, Larkin EK, Shankar J, et al. Respiratory syncytial virus whole-genome sequencing identifies convergent evolution of sequence duplication in the C-terminus of the G gene. Sci Rep. 2016;23:26311

16. Slovic A, Ivancic-Jelecki J, Ljubin-Sternak S, Galinović Mlinarić G, Forcic D. A molecular epidemiological study of human respiratory syncytial virus in Croatia, 2011-2014. Infect Genet Evol. 2016:44:76-84.

17. Chomczynski P, Mackey K. Single-step method of total RNA isolated by acid guanidine phenol extraction. In: Celis JE, editor. Cell biology: a laboratory handbook. 2nd ed. Amsterdam: Academic Press; 1998. p. $221-4$.

18. Hardy RW, Harmon SB, Wertz GW. Diverse gene junctions of respiratory syncytial virus modulate the efficiency of transcription termination and respond differently to M2-mediated antitermination. J Virol. 1999;73: 170-6.

19. Moudy RM, Harmon SB, Sullender WM, Wertz GW. Variations in transcription termination signals of human respiratory syncytial virus clinical isolates affect gene expression. Virology. 2003;313:250-60.

20. Moudy RM, Sullender WM, Wertz GW. Variations in intergenic region sequences of human respiratory syncytial virus clinical isolates: analysis of effects on transcriptional regulation. Virology. 2004;327:121-33.

21. Galiano MC, Palomo C, Videla CM, Arbiza J, Melero JA, Carballal G. Genetic and antigenic variability of human respiratory syncytial virus (groups a and B) isolated over seven consecutive seasons in Argentina (1995 to 2001). J Clin Microbiol. 2005;43:2266-73.

22. Peret TC, Hall CB, Schnabel KC, Golub JA, Anderson LJ. Circulation patterns of genetically distinct group a and $B$ strains of human respiratory syncytial virus in a community. J Gen Virol. 1998:79:2221-9.

23. Ivancic-Jelecki J, Forcic D, Mlinaric-Galinovic G, Tesovic G, Nikic Hecer A Early evolution of human respiratory syncytial virus ON1 strains: analysis of the diversity in the C-terminal hypervariable region of glycoprotein gene within the first 3.5 years since their detection. Intervirology. 2015; 58:172-80.

24. Trento A, Ábrego L, Rodriguez-Fernandez R, González-Sánchez MI, González-Martínez F, Delfraro A, et al. Conservation of G-protein epitopes in respiratory syncytial virus (group a) despite broad genetic diversity: is antibody selection involved in virus evolution? J Virol. 2015; 89:7776-85

25. Tan L, Lemey P, Houspie L, Viveen MC, Jansen NJ, van Loon AM, et al. Genetic variability among complete human respiratory syncytial virus subgroup a genomes: bridging molecular evolutionary dynamics and epidemiology. PLoS One. 2012;7:e51439.

26. Botosso VF, Zanotto PM, Ueda M, Arruda E, Gilio AE, Vieira SE, et al. Positive selection results in frequent reversible amino acid replacements in the $\mathrm{G}$ protein gene of human respiratory syncytial virus. PLoS Pathog. 2009;5: e1000254.

27. Zlateva KT, Lemey P, Moës E, Vandamme AM, Van Ranst M. Genetic variability and molecular evolution of the human respiratory syncytial virus subgroup B attachment G protein. J Virol. 2005;79:9157-67.

28. Lima HN, Botosso VF, Oliveira DB, Campos AC, Leal AL, Silva TS, et al. Molecular epidemiology of the SH (small hydrophobic) gene of human respiratory syncytial virus (HRSV), over 2 consecutive years. Virus Res. 2012; 163:82-6

29. Chen MD, Vazquez M, Buonocore L, Kahn JS. Conservation of the respiratory syncytial virus SH gene. J Infect Dis. 2000;182:1228-33.

30. Li Y, To J, Verdià-Baquena C, Dossena S, Surya W, Huang M, et al. Inhibition of the human respiratory syncytial virus small hydrophobic protein and structural variations in a bicelle environment. J Virol. 2014; 88:11899-914. 
31. Araujo GC, Silva RH, Scott LP, Araujo AS, Souza FP, de Oliveira RJ. Structure and functional dynamics characterization of the ion channel of the human respiratory syncytial virus (hRSV) small hydrophobic protein $(\mathrm{SH})$ transmembrane domain by combining molecular dynamics with excited normal modes. J Mol Model. 2016;22:286.

32. Torres J, Surya W, Li Y, Liu DX. Protein-protein interactions of Viroporins in coronaviruses and paramyxoviruses: new targets for antivirals? Viruses. 2015; 7:2858-83.

Ready to submit your research? Choose BMC and benefit from:

- fast, convenient online submission

- thorough peer review by experienced researchers in your field

- rapid publication on acceptance

- support for research data, including large and complex data types

- gold Open Access which fosters wider collaboration and increased citations

- maximum visibility for your research: over $100 \mathrm{M}$ website views per year

At BMC, research is always in progress.

Learn more biomedcentral.com/submissions 